Original Paper

\title{
Penggunaan Media Pembelajaran untuk Meningkatkan Prestasi Belajar Siswa Bidang Studi Perekayasaan Sistem Radio dan Televisi dengan Kompetensi Dasar Prinsip Kerja Televisi Warna
}

\author{
Abdul Kadir 1* \\ ${ }^{1}$ Sekolah Menengah Kejuruan Negeri 3 Mataram, Kota Mataram, Nusa Tenggara Barat, Indonesia
}

*Corresponding Author:

Abdul Kadir, Sekolah

Menengah Kejuruan Negeri 3

Mataram, Kota Mataram, Nusa

Tenggara Barat, Indonesia.

Email:

kadirhz379@gmail.com

\begin{abstract}
Abstrak: Penelitian ini bertujuan untuk untuk mengetahui penggunaan media pembelajaran yang efektif dalam meningkatkan prestasi belajar siswa bidang studi Perekayasaan Sistem Radio dan Televisi kelas XI SMK Negeri 3 Mataram Tahun Pelajaran 2018/2019. Penelitian ini menggunakan rancangan Penelitian Tindakan Kelas (Classroom Action Research). Subjek penelitian ini adalah siswa kelas XI Teknik Audio Video yang berjumlah 34 orang yang terdiri dari 31 orang putra dan 3 orang putri dan objek penelitian ini adalah media pembelajaran rangkaian blok penerima telvisi warna yang merupakan pendukung dalam proses pembelajaran. Pengambilan data dalam penelitian ini mengunakan instrumen proses dan instrumen hasil lembar Kerja Siswa (LKS). Keberhasilan dalam penelitian ini dapat dilihat dari aktivitas siswa dan guru saat proses pembelajaran berlangsung dengan menggunakan media secara efektif sehingga secara individual memperoleh nilai minimal mencapai KKM 7,0 dan secara kualitas yaitu prosentase jumlah siswa yang menunjukkan minat, kretivitas, kerjasama, dan keaktifan dalam proses pembelajaran mencapai minimal $80 \%$ ketuntasan. Hasil penelitian menunjukkan bahwa penggunaan media pembelajaran sebagai media atau alat bantu pembelajaran dapat meningkatkan prestasi belajar siswa bidang studi Sistem Penerima Televisi Warna kelas XI Semester Genap SMK Negeri 3 Mataram Tahun Pelajaran 2018/2019
\end{abstract}

Kata kunci: Media pembelajaran; Prestasi belajar; Kompetensi Dasar.

\section{Pendahuluan}

Pendidikan mendapat perhatian diberbagai negara baik di negara-negara yang sudah maju maupun Negara-negara yang sedang berkembang, disamping itu pendidikan merupakan cermin kemajuan suatu bangsa dan Negara (Setiawan, 2017). Di dalam Undang-Undang Dasar 45 Pasal 30 ayat 1 (UUD 1945, 1978: 7) dijelaskan bahwa setiap warga negara berhak mendapatkan pengajaran.

Dalam hal ini berarti secara umum ditekankan agar semua warga negara Indonesia diharapkan untuk menuntut ilmu pengetahuan sesuai dengan kemampuan yang dimilikinya masing-masing tanpa ada perkecualian. Disamping itu pula di dalam Garis-Garis Besar Haluan Negara (GBHN TAP MPR No. II/MPR/1983 : 90) dijelaskan bahwa pendidikan nasional berdasrkan Pancasila 
bertujuan untuk meningkatkan ketaqwaan terhadap Tuhan Yang Maha Esa, mempertinggi budi pekerti, memperkuat kepribadian dan mempertebal semangat kebangsaan dan cita-cita tanah air, agar dapat menumbuhkan manusia pembangunan yang dapat membangun dirinya sendiri dan bersama-sama bertanggungjawab atas pembangunan bangsanya.

Dengan memperhatikan hal-hal tersebut di atas agar pendidikan bisa berhasil sebagaimana yang diharapkan, maka disini dapat dikemukakan beberapa faktor pendukung seperti 1) adanya penyediaan alat dan bahan yang sesuai dengan tuntutan kurikulum, 2) adanya tenaga pengajar yang terlatih dan terdidik sesaui dengan jurusan spesialisasinya, 3) adanya perencanaan dan penyempurnaan kurikulum yang disesuaikan dengan keadaan dan perkembangan zaman, dan 4) adanya penggunaan dan pemeliharaan alat dan bahan yang ada dengan seefisien mungkin.

Saat ini pemerintah Indonesia sedang giatnya melaksanakan pembangunan disegala bidang terutama bidang pendidikan yang bertujuan untuk meningkatkan mutu pendidikan nasional, baik dari sekolah tingkat Taman Kanak-kanak sampai tingkat perguruan tinggi. Sebagaimna contohnya telah banyak kita lihat perkembangan yang dapat kita nikmati bersama, misalnya dalam hal berbagai jenis media pembelajaran yang dapat meningkatkan proses pembelajaran. Dengan semakin meningkatnya media pembelajaran berarti semua ini merupakan dukungan pasilitas yang menunjang tercapainya proses pembelajaran.

Media pembelajaran adalah alat, metode, dan teknik yang digunakan dalam rangka mengefektifkan komunikasi dan interaksi antara guru dan siswa dalam proses pendidikan dan pengajaran di sekolah (Hamalik, 1982). Maka jelas sekali bahwa penggunaan media pembelajaran dalam proses pembelajaran sangat penting untuk dilakukan.

Media merupakan kata dari bahasa Latin dan digunakan untuk mendeskripsikan cara untuk mengekspresikan pesan-pesan dan informasi (Setiawan, 2017). Suatu media bisa disebut sebagai media pembelajaran jika media tersebut menyediakan pesan dan informasi untuk keperluan pembelajaran (Smaldino \& Russell 2011). Sehingga media pembelajaran pada prinsipnya adalah sebuah proses komunikasi antara guru dan peserta didik, yakni proses penyampaian pesan yang diciptakan melalui suatu kegiatan penyampaian dan tukar menukar pesan atau informasi oleh setiap guru dan peserta didik. Pesan dan Informasi dapat berupa pengetahuan, keahlian, skill, ide, pengalaman dan sebagainya.

Tentunya bila faktor-faktor yang dapat mempengaruhi keberhasilan pendidikan tidak memadai, maka didalam proses pembelajaran akan terjadi hambatan-hambatan yang mengakibatkan tidak tercapainya tujuan sebagaimana yang diharapkan. Dan berdasarkan hasil observasi, pada tahun pelajaran 2018/2019, diperoleh data seperti Tabel 1.

Tabel 1. Data Keberhasilan Siswa Tahun Pelajaran 2018/2019

\begin{tabular}{llllllll}
\hline \multirow{2}{*}{ No } & \multirow{2}{*}{ Jumlah Siswa } & \multicolumn{2}{c}{ Sebelum Menggunakan Media } & \multicolumn{3}{c}{ Sesudah Menggunakan Media } \\
& & Berhasil & Gagal & \% Berhasil & Berhasil & Gagal & $\%$ Berhasil \\
\hline 1 & 34 & 18 & 16 & $52,941 \%$ & 30 & 4 & $88,235 \%$ \\
\hline
\end{tabular}

Melihat

melaksanakan pembelajaran kenyataannya selama penelitian, saat proses berlangsung ternyata penggunaan media pembelajaran dalam proses pembelajaran masih kurang efektif, khususnya pada bidang studi Perekayasaan Sistem Radio dan Televisi Program Keahlian Teknik Audio Vedeo. Hal ini disebabkan karena media pembelajaran yang ada di sekolah khususnya Program Keahlian Teknik 
Audio Video masih kurang, karena semakin sering menggunakan media pembelajaran maka semakin berhasillah pencapaian tujuan, artinya apabila guru dapat menggunakan media yang tepat dan disesuaikan dengan bahan pembelajaran, situasi dan kondisi, maka semakin berhasillah tujuan pembelajaran yang ingin dicapai.

Dalam kegiatan pembelajaran diupayakan materi pelajaran yang disampaikan kepada siswa dapat diserap dengan memerlukan kematangan dan pertumbuhan potensi-potensi jasmaniah dan rohaniahnya, oleh sebab itu materi pelajaran harus disesuaikan dengan pertumbuhan siswa dan taraf kecerdasannya (Purwanto, 1992). Khusus mengenai pembelajaran bidang studi Perekayasaan Sistem Radio dan Televisi bukan hanya untuk mendapatkan fakta-fakta, konsep-konsep, dan pengertian dari prinsip kerja sistem penerima televisi dan bagianbagian dari penerima televisi saja, melainkan untuk pengembangan keterampilan, misalnya mampu menginstalasi televisi dengan peralatan elektronika lain, dan yang paling penting adalah mampu memperbaiki bila televisi tersebut megalami gangguan (trobel), serta bersikap untuk memecahkan masalahmasakah yang dihadapinya dalam kehidupan sehari-hari. Karena pengetahuan tidak hanya dengan membaca buku dan mendengar ceramah guru saja, melainkan harus disertai kegiatan-kegiatan lain yang dilakukan oleh siswa sendiri yaitu melakukan penyelidikan, penyusunan dan pengujian gagasan-gagasan melalui eksperimen. Dengan melibatkan anak dalam kegiatan pembelajaran akan dapat mengembangkan kreativitas dan aktifitas pada anak, sehingga dengan mudah anak menyerap materi yang diajarkan.

\section{Metode}

Penelitian ini menggunakan rancangan Penelitian Tindakan Kelas (Classroom Action Research). Lokasi penelitian di SMK Negeri 3
Mataram ynag terletak di Jl. Pendidikan No. 47 Mataram, Kecamatan Mataram. Penelitian ini dilakukan dalam waktu 3 bulan, yaitu dari bulan Pebruari sampai dengan bulan April 2019. Subjek penelitian ini adalah siswa kelas XI Teknik Audio Video yang berjumlah 34 orang yang terdiri dari 31 orang putra dan 3 orang putri dan objek penelitian ini adalah media pembelajaran rangkaian blok penerima telvisi warna yang merupakan pendukung dalam proses pembelajaran.

Penelitian ini dilaksanakan berdasarkan prosedur Penelitian Tindakan Kelas. Gambaran siklus penelitian menurut Kemmist dan MC. Taggart (1992) dapat dilihat pada Gambar 1.

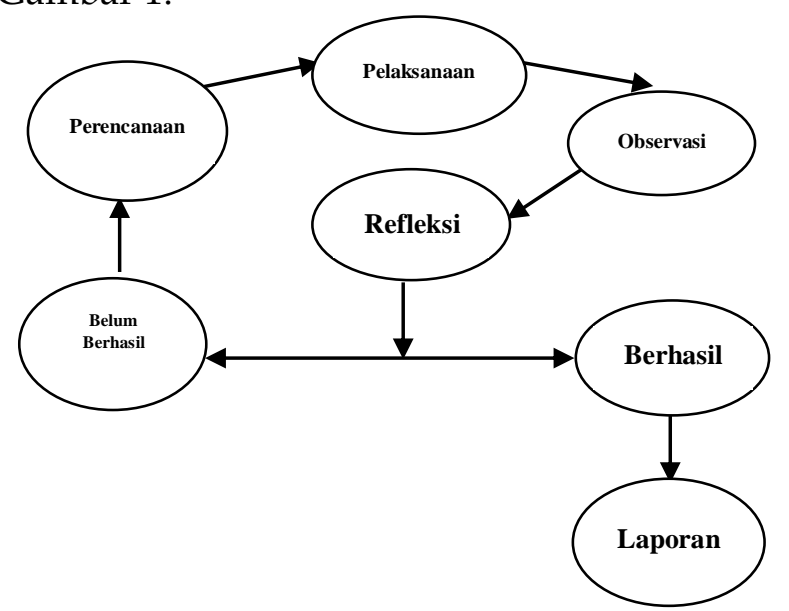

Gambar 1. Siklus Penelitian Menurut Kemmist dan MC. Taggart (1992)

Pengambilan data dalam penelitian ini mengunakan: 1) Instrumen proses seperti lembar observasi guru berupa hasil pelaksanaan pembelajaran dan lembar observasi siswa berupa kemajuan siswa/motivasi dalam belajar. 2) Instrumen hasil seperti lembar Kerja Siswa (LKS) yang berisi hasil kerja siswa, dan lembar evaluasi berisi tugas secara individu yang dilaksanakan oleh siswa.

Teknik pengumpulan data hasil penelitian yang dilakukan dengan cara: 1) Data prestasi belajar siswa yaitu data yang dikumpulkan dengan memberikan tes pada siswa dalam bentuk essay, tes ini diberikan setelah berakhirnya proses pembelajaran. 2) 
Data aktivitas guru dan Siswa yaitu data yang dikumpulkan dengan menggunakan metode observasi, dengan menggunakan lembar observasi. 3) Sumber datanya adalah siswa kelas XI semester genap Tahun Pelajaran 2018/2019.

Analisis data hasil observasi pada penelitian ini mengacu pada lembar observasi guru dan siswa. Analisis data dari lembar observasi guru diperoleh dari indikator prilaku yang tampak berdasarkan penilaian observer, sedangkan analisis data dari lembar observasi siswa diperoleh dari banyaknya prilaku siswa yang tampak pada kegiatan pembelajaran yang dinilai oleh peneliti/guru. Prilaku tersebut ditunjukkan dalam sejumlah deskriptor, dan penskoran dilakukan dengan cara sebagai berikut :

a. Skor 5 diberikan jika $81 \%$ - $100 \%$ melakukan deskriptor yang dimaksud.

b. Skor 4 diberikan jika $61 \%$ - $80 \%$ melakukan deskriptor yang dimaksud.

c. Skor 3 diberikan jika $41 \%$ - $60 \%$ melakukan deskriptor yang dimaksud.

d. Skor 2 diberikan jika $21 \%$ - $40 \%$ melakukan deskriptor yang dimaksud.

e. Skor 1 diberikan jika $0 \%-20 \%$ melakukan deskriptor yang dimaksud.

Pedoman skor standar dijelaskan pada Tabel 2.

Tabel 2. Pedoman Skor Standar Aktivitas Belajar Siswa dan Aktivitas Mengajar Guru

\begin{tabular}{ll}
\hline Interval & Kategori \\
\hline $\mathrm{AS} \geq \mathrm{MI}+1,5 \mathrm{SDI}$ & Sangat Aktif \\
$\mathrm{MI}+0,5 \mathrm{SDI} \leq \mathrm{AS}<\mathrm{MI}+1,5 \mathrm{SDI}$ & Aktif \\
$\mathrm{MI}-0,5 \mathrm{SDI} \leq \mathrm{AS}<\mathrm{MI}+0,5 \mathrm{SDI}$ & Cukup Aktif \\
$\mathrm{MI}-1,5 \mathrm{SDI} \leq \mathrm{AS}<\mathrm{MI}-0,5 \mathrm{SDI}$ & Kurang Aktif \\
$0 \leq \mathrm{AS}<\mathrm{MI}-1,5 \mathrm{SDI}$ & Sangat Kurang \\
& Aktif \\
\hline
\end{tabular}

(Sukmawati \& Purnamasari , 2016)

Mengacu pada pedoman skor aktivitas belajar siswa dan aktivitas mengajar guru, maka dapat diperoleh Skor Maksimal Ideal (SMI) yang merupakan skor tertinggi aktivitas yang didapat apabila semua deskriptor yang diamati nampak yaitu skor 5 di tambah dengan skor terendah aktifitas siswa yaitu:
1. Untuk menilai kategori aktifitas siswa, ditentukan terlebih dahulu MI (Mean Ideal) dan SDI (Standar Deviasi Ideal). Cara menentukan MI dan SDI adalah sebagai berikut :

$$
\begin{aligned}
& \mathrm{MI}=\frac{S \mathrm{MI}(\mathrm{max})+\mathrm{SMI}(\mathrm{min})}{2} \\
& \mathrm{SDI}=\frac{1}{3} \mathrm{x} \mathrm{MI}
\end{aligned}
$$

2. Analisis data hasil belajar diambil dari hasil pengamatan, analisis data hasil evaluasi diperoleh dalam proses pembelajaran. Adapun aspek-aspek yang dinilai adalah penggunaan media pembelajaran yang efektif dalam mengalisa blok-blok televisi, menjelaskan fungsi setiap blok, membuat jalur PCB masing-masing blok, dan melakukan trouble shoting pada mineboard televisi yang digunakan sebagai media pembelajaran.

Keberhasilan dalam penelitian ini dapat dilihat dari aktivitas siswa dan guru/peneliti saat proses pembelajaran berlangsung, yaitu guru dan siswa secara efektif menggunakan mineboard televisi sebagai media pembelajaran pada saat mengalisa rangkaian televisi. Dengan menggunakan media secara efektif memperoleh hasil sebagaimana yang direncanakan, baik secara kuantitas dengan memperoleh nilai minimal mencapai KKM 7,0 maupun secara kualitas yaitu prosentase jumlah siswa yang menunjukkan minat, kretivitas, kerjasama, dan keaktifan dalam proses pembelajaran mencapai minimal $80 \%$ ketuntasan.

\section{Hasil dan Pembahasan}

Penelitian ini dilaksanakan di SMK Negeri 3 Mataram. Penelitian ini dilakukan untuk meningkatkan kemampuan siswa dalam menjelaskan prinsip kerja sistem penerima televisi warna pada siswa kelas XI semester genap Tahun Pelajaran 2018/2019. Penelitian ini direncanakan berlangsung dua 
siklus dan masing-masing siklus terdiri dari dua tahap yaitu tahap perencanaan, tindakan, observasi dan tahap refleksi serta evaluasi.

\section{Siklus I}

Siklus pertama untuk pembelajaran dengan menggunakan media pembelajaran ini dilaksanakan pada hari Selasa, 11 Pebruari 2019. Berdasarkan hasil observasi terdapat beberapa kendala, diantaranya adalah konsentrasi belajar siswa yang tidak maksimal dan ketersediaan media pembelajaran tidak sesuai dengan jumlah siswa, yang mengakibatkan hasil proses pembelajaran tidak mencapai KKM. Tetapi walaupun ada kendala tersebut terdapat beberapa siswa yang memperoleh hasil sama dan atau lebih dari KKM, sebagaimana terlihat pada lampiran 10 data nilai menganalisa rangkaian televisi. Pada siklus ini materi yang disampaikan adalah tentang menganalisa blok penala, dalam hal ini mineboard televisi sebagai medianya. Adapun langkah-langkah yang dilakukan dalam menganalisa adalah sebagai berikut :

\section{1) Perencanaan}

Sebelum melakukan penelitian terlebih dahulu peneliti membuat perencanaan penelitian seperti waktunya, lokasinya, kelas, dan bidang studinya. Dalam perencanaannya peneliti mengambil topik penggunaan media pembelajaran pada bidang studi sistem penerima televisi warna, yang selama ini dirasakan sangat kurang. Sedangkan kelebihan yang peneliti rasakan adalah adanya workshop pembuatan PTK, adanya suntikan dana dari pemerintah, dan adanya dukungan dari teman-teman sejawat serta orang-orang yang paling dekat dengan peneliti.

\section{2) Pelaksanaan Tindakan}

Tahap pelaksanaan tindakan ini, dilakukan sesuai dengan perencanaan penelitian, yaitu penggunaan media dalam proses pembelajaran bidang studi sistem penerima televisi warna, yang dilakukan terdiri dari satu tujuan khusus/kompetensi dasar yaitu tentang blok pernala. Dalam pelaksanaan penelitian tersebut terdapat beberapa kekurangan, yaitu konsentrasi belajara siswa yang tidak maksimal, ketersediaan media pembelajaran tidak sesuai dengan jumlah siswa, masih membutuhkan dana untuk menambah kekurangan dana yang diberikan, pelaksanaan penelitian berubah dari rencana karena adanya pelaksanaan Uji Kompetensi, Ujian Sekolah, dan Ujian Nasional bagi kelas XII. Disamping itu juga berdasarkan data saat peneliti memberikan pertanyaan, hanya 5 orang siswa yang bersemangat menjawab yaitu : Hamdi Irawan, Anandita Cika Maharani H, Husnul Khotimah, L. Ahm. Hafiz Latofa, dan Wanda Iswari. Sedangkan kelebihan yang dirasakan dalam melaksanakan penelitian ini adalah pelaksanaan penelitian berjalan dengan lancar, siswa merasa lebih memperhatikan karena ada bimbingan secara intensip dilakukan setiap adanya masalah yang dihadapi siswa, mental dan motivasi siswa semakin bagus karena adanya kerja kelompok yang dilanjutkan dengan diskusi untuk membahas materi yang dianalisa, siswa belajar dan menganalisa secara langsung terhadap materi yang diberikan.

Kelebihan yang dirasakan oleh pelaksana penelitian adanya dukungan dari tim sejawat, observer, maupun guru lain yang mengakibatkan proses pembelajaran memperoleh hasil yang memuaskan yaitu 30 orang dari 34 orang siswa yang tuntas atau $88,235 \%$ pada siklus II, bila dibandingkan dengan siklus I hanya 18 orang siswa yang tuntas atau 52,941\%.

\section{3) Hasil Observasi dan Evaluasi}

Yang bertindak sebagai observer dalam penelitian ini dilakukan oleh seorang teman sejawat yaitu : Bapak Muliasih, ST yang bertugas mengamati guru dan siswa selama pembelajaran berlangsung. Kegiatan yang dilakukan oleh observer adalah mengamati tindakan yang dilakukan oleh guru saat mengajar dan siswa dari awal pembelajaran 
menganalisa blok penala televisi sampai mengakhiri pembelajaran, sehingga selama pembelajaran berlangsung diperoleh data sebagaim berikut:

\section{a. Hasil Pengamatan Aktivitas Mengajar Guru}

Berdasarkan data pengamatan dari teman sejawat/tim pengamat pada aktivitas mengajar guru menunjukkan bahwa guru dalam mempersiapkan Rencana Pelaksanaan Pembelajaran (RPP) belum memenuhi standar ketuntasan yaitu masih tergolong kurang baik. Aktivitas mengajar guru cukup baik dalam membimbing siswa yang betul-betul mengalami kesulitan. Dalam penggunaan media pembelajaran masih terbatas, artinya setiap kelompok hanya satu mineboard televisi saja sehingga masih ada sebagian siswa yang bermain atau ngobrol, maka untuk memberikan motivasi siswa digunakanlah televisi, laptop, dan LCD. Disamping itu pula guru masih kurang dalam memberikan penguatan sehingga siswa kurang juga dalam berpartisipasi, dan kurang aktif dalam kegiatan kelompok maupun kegiatan klasikal. Siswa masih banyak yang belum selesai mengerjakan LKSnya karena kehabisan waktu, hal ini dimungkinkan penyebabnya masih ada siswa yang ragu-ragu atau belum berani menuangkan pikirannya dalam bentuk tulisan, sebagaimana pada lampiran 3 Lembar Observasi aktivitas mengajar guru siklus I pertemuan 1.

Dari data tersebut dapat dilihat bahwa aktivitas yang masih jarang dilakukan oleh guru adalah memberikan kesempatan siswa bertanya kepada guru dan mengarahkan siswa dalam bekerjasama kelompok, sehingga persentase ketercapaiannya hanya $50 \%$. Aktivitas yang sering muncul dan kadangkadang dilakukan oleh guru adalah mengkondisikan siswa, menjelaskan tujuan pembelajaran, memperkenanlkan alat bantu/media pembelajaran, memberikan penghargaan, dan mengadakan refleksi. b. Hasil Pengamatan Aktivitas Belajar Siswa

Pada tahapan ini guru dan pengamat lain mengamati aktivitas belajar siswa selama pembelajaran. Aspek yang diamati adalah kegiatan pra pembelajaran, aktivitas belajar siswa selama pembelajaran, aktivitas belajar siswa dalam diskusi kelompok. Berdasarkan data hasil pengamatan observer, siswa dalam mengerjakan tugas dan memperhatikan penjelasan guru serta merespons apa yang disampaikan oleh guru. Namun masih ada beberapa siswa yang kurang termotivasi dalam belajar, ada kelompok siswa yang kurang berpartisipasi dalam diskusi. Pada evaluasi masih ada siswa yang belum selesai mengerjakan tugas, hal ini disebabkan karena masih ada beberapa siswa dalam kelompoknya kurang respon dengan tugas yang diberikan, sebagaimana terlihat pada lampiran 4 Lembar observasi aktivitas belajar siswa siklus I pertemuan 1.

Berdasarkan data tersebut dapat dilihat bahwa aktivitas yang sering dilakukan siswa adalah mereka sudah memperhatikan penjelasan guru, dan aktif mengamati dan menganalisa rangkaian televisi sebagai media pembelajaran dan penjelasan guru yang yang ditampilkan lewat LCD, sehingga persentase ketercapaiannya mencapai $100 \%$, sedangkan aktivitas yang masih jarang dilakukan oleh siswa adalah keinginan bertanya kepada guru. Aktivitas ini jarang dilakukan karena masih ada perasaan ragu dari siswa, sehingga persentase ketercapaiannya hanya $50 \%$.

c. Hasil Evaluasi Menganalisa Rangkaian TV.

Pada siklus I hasil evaluasi siswa kelas XI dalam menganalisa rangkaian televisi dapat dilihat pada lampiran 10 data nilai menganalisa rangkaian tv siklus I. Berdasarkan hasil data kemampuan siswa tersebut yang tuntas hanya 18 orang dari 34 orang siswa atau 52,941\%, hal ini disebabkan masih ada siswa yang mendapat nilai di bawah KKM, oleh karena itu penelitian pada siklus I ini dilanjutkan ke siklus II. Cara menghitung ketuntasan kelasikal (KK) : 


$$
\begin{aligned}
\text { KK } & =\frac{\text { Jumlah siswa yang tuntas }}{\text { Jumlah siswa seluruhnya }} \times 100 \% \\
& =\frac{18}{34} \times 100 \% \\
& =52,941 \%
\end{aligned}
$$

Pada hari yang sama yaitu Selasa, 25 Pebruari 2019 setelah pelaksanaan tindakan siklus I, diadakan refleksi terhadap hasil pengamatan atau temuan-temuan selama pelaksanaan tindakan. Refleksi dilakukan di bengkel praktik TV kelas XI Teknik Audio Video oleh peneliti dan pengamat/observer. Adapun komentar atau saran yang diberikan oleh observer adalah :

1. Guru sudah mengkondisikan siswa dengan baik sebelum memulai proses pembelajaran, namun karena mineboard TV terbatas dengan ukuran dan tipe yang berbeda, maka masih ada beberapa siswa yang tidak serius dalam menganalisa rangkaian TV.

2. Guru juga sudah menyampaikan tujuan pembelajaran yang akan dicapai hari itu.

3. Guru juga sudah menyampaikan materi pelajaran dengan baik dan memberi penghargaan kepada siswa.

4. Guru masih kurang membimbing dan memberikan penguatan kepada siswa.

5. Masih ada siswa yang tidak aktif dalam kegiatan pembelajaran.

6. Masih ada siswa yang belum selesai mengerjakan tugas yang diberikan oleh guru.

Dengan melihat adanya kekurangankekurangan yang ada pada siklus I, maka peneliti akan melakukan perbaikan-perbaikan pada siklus selanjutnya. Adapun perbaikanperbaikan yang akan dilakukan pada siklus selanjutnya yaitu : 1) Guru akan lebih mengkondisikan siswa sehingga guru dapat menyampaikan materi pelajaran dengan baik. 2) Guru juga akan lebih membimbing siswa yang kurang dalam menganalisa pesawat televisi dan aktif mendampingi siswa dalam mengerjakan tugas agar dapat diselesaikan tepat waktu.

\section{Siklus II}

\section{1) Perencanaan}

Siklus II untuk pembelajaran dengan menggunakan media pembelajaran ini dilaksanakan pada hari Selasa, 11 Maret 2019. Pada siklus ini materi yang dibahas adalah blok IF dengan mengamati langsung pada blok tersebut. Perencanaan penelitian pada siklus II tidak terlalu jauh perbedaannya dengan siklus I, sehingga kekurangan pada siklus I coba diperbaiki pada siklus II terutama dalam meningkatkan motivasi belajar siswa, sedang media pembelajaran yang merupakan tolak ukur keberhasilan proses pembelajaran diusahakan dengan memperbanyak pesawat tv-nya, yaitu dengan memperbaiki tv yang rusak. Adapun hal-hal yang dipersiapkan peneliti pada sikus II ini adalah :

1. Membuat skenario pembelajaran siklus II yang disusun berdasarkan hasil refleksi pada siklus I.

2. Peneliti menyiapkan lembar observasi untuk mencatat aktivitas siswa dan guru pada siklus II yang formatnya sama dengan siklus I.

3. Menyiapkan Lembar Kerja Siswa (LKS) dengan lebih baik.

4. Menyiapkan media pembelajaran yang lebih lengkap dengan jumlahnya disesuaikan dengan jumlah siswa.

\section{2) Pelaksanaan Tindakan}

Tahap pelaksanaan siklus II, peneliti berusaha mengupayakan pembelajaran lebih efektif dan menyenangkan dari siklus sebelumnya. Pelaksanaan siklus II sama dengan siklus I, hanya saja ada perubahan dalam menggunakan semua media pembelajaran. Media tidak hanya dengan menggunakan Laptop dan LCD, namun siswa mengamati langsung pada pesawat televisinya yang akan dianalisa. Hal ini menyebabkan siswa bersemangat untuk belajar karena mereka langsung melaksanakan praktik. Siswa terlihat antusias dalam belajar dan tidak ada lagi siswa yang malu bertanya. 


\section{3) Hasil Pengamatan}

Pada tahap observasi ini dilakukan guru yang bertugas sebagai pengajar sekaligus mengamati siswa. Kegiatan yang dilakukan pengamat adalah mengamati kegiatan yang dilakukan guru dan siswa sampai akhir pembelajaran.

\section{a) Hasil Pengamatan Aktivitas Mengajara Guru}

Berdasarkan data pengamatan dari teman sejawat/tim pengamat, aktivitas mengajar guru dalam membimbing terlaksana dengan baik. Guru memanfaatkan media pembelajaran dengan baik yaitu dengan mengajak siswa belajar menemukan sendiri blok-blok yang ada pada mineboard tv yang akan mereka analisa. Penguatan yang diberikan guru membuat siswa termotivasi dalam belajar dan aktif. Siswa dapat menyelesaikan tugasnya dengan baik yaitu membuat laporan hasil analisa tv sesuai dengan waktu yang telah ditentukan, hal ini dikarenakan tidak ada siswa yang bermainmain, sebagaimana terlihat pada lampiran 12 Lembar observasi aktivitas mengajar guru siklus pertama pertemuan 1 .

Dari lampiran 12 dapat dilihat bahwa aktivitas mengajar guru dalam kesiapan guru melaksanakan pembelajaran, menggunakan media pembelajaran, aktivitas dalam pembelajaran, dan menciptakan suasana yang kondusif, memperolah skor 4,5 dengan katagori baik. Angka ini merupakan skor hampir maksimal sehingga dapat dikatakan kegiatan-kegiatan tersebut sering dilakukan. Dengan melihat tabel di atas maka dapat diketahui bahwa aktivitas mengajar guru pada siklus II mengalami peningkatan.

b) Hasil Pengamatan Aktivitas Belajar Siswa

Pada tahap ini guru dan observer mengamati aktivitas belajar siswa dalam penggunaan media pembelajaran. Dari hasil observasi aktivitas belajar siswa pada siklus II ini menunjukkan sebagian besar siswa sudah terlihat antusias untuk menerima pelajaran.
Dan ketika diajak untuk menganalisa rangkaian televisi sebagai media pembelajaran, siswa terlihat sangat bersemangat untuk belajar. Dalam proses pembelajaran juga tidak terlihat lagi siswa yang kurang bersemangat dalam belajar. Mereka terlihat lebih banyak menganalisa bagian-bagian yang ada pada mineboard TV sebagai tugas yang diberikan oleh guru. Untuk melihat lebih jelas data observasi aktivitas belajar siswa dalam menggunakan media saat proses pembelajaran dapat dilihat pada lampiran 13 Lembar observasi aktivitas belajar siswa siklus II pertemuan I. Dan berdasarkan data tersebut pada siklus ini mengalami peningkatan dibandingkan pada siklus I.

\section{c) Hasil Evaluasi Siklus II}

Pada siklus II hasil evaluasi kelas XI Teknik Audio Video dalam menganalisa prinsip kerja televisi penerima adanya peningkatan hasil belajar siswa dari siklus I. Pada siklus I siswa yang tuntas ada 18 orang dengan porsentase 52,941 \%. Penelitian ini dikatakan berhasil jika hasil belajar siswa dengan menggunakan media pembelajaran memperoleh hasil dan atau lebih dari KKM dengan pencapaian ketuntasan kelas minimal $80 \%$. Dan berdasarkan data penelitian bahwa pada siklus II ini ketuntasan kelas diperoleh $88,235 \%$, yang berarti pelaksanaan penelitian pa da siklus II dinyatakan berhasil dan penelitian dihentikan. Cara menghitung ketuntasan kelasikal (KK) :

$$
\begin{aligned}
\mathrm{KK} & =\frac{\text { Jumlah siswa yang tuntas }}{\text { Jumlah siswa seluruhnya }} \times 100 \% \\
& =\frac{30}{34} \times 100 \% \\
& =88,235 \%
\end{aligned}
$$

Setelah pelaksanaan kegiatan siklus II selesai langsung diadakan refleksi terhadap temuan-temuan pada kegiatan di siklus II. Refleksi dilakukan di bengkel praktek TV oleh peneliti dan observer. Dalam pelaksanaan pembelajaran pada siklus II ada beberapa masukan yang diberikan oleh observer, antara 
lain: 1) Guru sudah benar-benar memanfaatkan media pembelajaran yang ada dalam siklus II. 2) Guru sudah maksimal dalam memberikan penguatan kepada siswa, sehingga siswa lebih aktif belajar, apalagi dengan bantuan media pembelajaran sehingga hasilnya jauh lebih baik dibandingkan pada siklus I.

Pada siklus I, peneliti dalam mengambil penilaian menganalisa rangkaian televisi penerima dengan menggunakan televisi dan mineboard televisi sebagai media pembelajaran. Dalam menganalisa tersebut berdasarkan kriteria : membagi blok, fungsi tiap blok, membuat jalur PCB, dan trouble shotting dengan tujuan untuk mengetahui sejauh mana kemampuan siswa kelas XI Teknik Audio Video tentang televisi. Adapun contoh hasil LKS siswa dalam menganalisa rangkaian televisi pada siklus I dari skor tertinggi sampai skor terendah.

Siswa yang tergolong memiliki kemampuan menganalisa rangkaian tv sebagaimana terlihat pada lampiran 10 dengan skor tertinggi (nilai 8) sebanyak 5 orang, dengan penskoran yaitu : membagi blok nilainya 2, fungsi setiap blok nilainya 2 , jalur PCB nilainya 2, dan trouble shotting nilainya 2. Pada siklus I ini mereka dapat menganalisa rangkaian TV dengan benar. Siswa yang memperoleh nilai 7,0 atau nilai standar KKM ada 10 orang dengan penskoran yaitu : membagi blok nilainya 2, fungsi setiap blok nilainya 2, jalur PCB nilainya 2, dan trouble shotting nilainya 1 . Sedangkan siswa yang memperoleh nilai di bawah KKM (nilai 4, 5, dan 6) ada 24 orang siswa.

Berdasarkan hasil analisis pada siklus II terjadi peningkatan hasil dalam proses pembelajaran, yaitu dari 52,941 \% pada siklus I naik menjadi $88,235 \%$ pada siklus II. Pada siklus II, peneliti tetap mengambil penilaian seperti pada siklus I yaitu penilaian menganalisa rangkaian televisi dan sebagai media pembelajaran adalah pesawat televisi dan mineboard TV dengan tujuan untuk mengetahui peningkatan kemampuan siswa kelas XI antara siklus I dengan siklus II.

Berdasarkan data yang diperoleh maka hasil belajar siswa menganalisa rangkaian televisi penerima sebagai media pembelajaran mengalami peningkatan pada siklus II. Dengan adanya peningkatan hasil pembelajaran tersebut, maka sangat diharapkan kepada semua guru untuk lebih efektif menggunakan media saat proses pembelajaran berlangsung.

Penelitian ini dilaksanakan sesuai dengan prosedur penelitian tindakan kelas yang telah ditetapkan dari awal dengan perencanaan, tindakan, observasi, dan refleksi. Pada siklus I data menunjukkan bahwa penggunaan media pembelajaran saat pelaksanaan proses pembelajaran yang diterapkan guru selama ini masih berpusat pada guru, artinya guru sebagai pusat pemberi informasi dan siswa hanya menerima. Siswa lebih banyak disuruh mendengarkan penjelasan guru secara abstrak tanpa mempraktekkan secara langsung. Dalam pembelajaran guru masih kurang menggunakan media pembelajaran yang bervariasi agar merangsang siswa untuk aktif dalam belajar. Untuk itu guru perlu menggunakan media pembelajaran dimana siswa sendiri menemukan apa yang dicarinya atau yang ingin diketahuinya. Media pembelajaran yang tepat digunakan adalah tv warna, mineboard tv warna, laptop, LCD. Dengan menggunakan media pembelajaran ini siswa diharapkan dapat meningkatkan kemampuan untuk mengetahui prinsip kerja secara utuh tentang televisi warna, sehingga siswa dengan sendirinya menemukan apa yang ingin diketahuinya.

Pada siklus I, guru tidak menggunakan media pembelajaran dalam menyusun Rencana Pelaksanaan Pembelajaran (RPP). Hasil pengamatan yang dilakukan oleh observer, guru masih kurang memberikan kesempatan kepada siswa untuk bertanya, dan masih siswa yang kurang antusias dalam belajar. Proses pembelajaran juga belum bisa 
dilaksanakan tepat waktu, karena masih ada siswa yang belum menyelesaikan tugas sesuai dengan waktu yang ditetapkan.

Dari hasil analisis data di kelas XI Teknik Audio Video pada siklus I hanya 18 orang siswa dari 34 orang atau 52,941 \% yang nilainya sama atau di atas KKM. Dengan melihat masih banyaknya siswa yang belum tuntas pada siklus I ini, maka peneliti dan observer sepakat untuk mengadakan siklus II.

Pada siklus II, guru membuat Rencana Pelaksanaan Pembelajaran (RPP) yang lebih baik dan dengan menggunakan media pembelajaran yang lebih efektif sebagai alat bantu yang dapat dianalisa langsung oleh siswa pada saat proses pembelajaran. Setelah dilakukan berbagai perbaikan pada siklus II, hasil observasi menunjukkan bahwa guru melaksanakan skenario pembelajaran dengan lebih baik. Hal ini tampak pada aktifnya siswa dalam pembelajaran dan adanya interaksi antara siswa dengan siswa dan siswa dengan guru. Siswa terlihat lebih cepat menganalisa rangkaian televisi dan mereka dapat menyelesaikan tugas yang diberikan tepat waktu. Dari hasil observasi aktivitas belajar siswa dan guru juga mengalami peningkatan dibandingkan pada siklus I.

Hasil perolehan siswa pada siklus ini juga menunjukkan peningkatan. Pada siklus I siswa yang tuntas hanya 18 orang atau sekitar $52,941 \%$ dari 34 siswa yang ada di kelas XI Teknik Audio Video. Pada siklus II ini jumlah siswa yang tuntas mencapai 30 orang siswa dari 34 siswa ataua 88,235\%. Dengan melihat ketuntasan pada siklus II ini menunjukkan bahwa pelaksanaan penelitian siklus II ini dinyatakan berhasil dan penelitian dihentikan.

\section{Kesimpulan}

Dari uraian dan pembahasana di atas dapat disimpulkan bahwa penggunaan media pembelajaran sebagai media atau alat bantu pembelajaran dapat meningkatkan prestasi belajar siswa bidang studi Sistem Penerima
Televisi Warna kelas XI Semester Genap SMK Negeri 3 Mataram Tahun Pelajaran 2018/2019.

\section{Daftar Pustaka}

Hamalik, O. (1986). Media Pendidikan. IKIP Bandung.

Kemmis, S \& Mc Taggart, R. (1992). The Action Research Planner. Australia: Deakin University Press.

Ketetapan Majelis Permusyawaratan Rakyat Republik Indonesia Nomor II/MPR/1983 Tahun 1983 Tentang Garis-Garis Besar Haluan Negara. Jakarta.

Setiawan, W.A. Pengembangan Media Pembelajaran Menggunakan Software Autoplay Media Studio 8 Pada Mata Pelajaran Perekayasaan Sistem Radio dan Televisi Kelas Xi AV di SMK Negeri 1 Sidoarjo. Jurnal Pendidikan Teknik Elektro. 6 (1) : 85-91

Smaldino, L. \& Russell. (2011). Instructional Technology and Media Learning. Jakarta: Kencana Prenada Media Group.

Sukmawati, R.A dan Purnamasari, W. 2016. Pembelajaran Matematika Menggunakan Model Pembelajaran Kooperatif Tipe Teams Games Tournament (TGT) di Kelas VIII SMP. EDU-MAT Jurnal Pendidikan Matematika, 4(1): 86 - 94

Undang-Undang Dasar Tahun 1945 Pasal 30 ayat. Jakarta. 